\title{
AUGUSTO ÓPẼ DA SILVA:UMA HISTÓRIA DE VIDA QUE MERECE SER CONTADA
}

\author{
ROGÉRIO REUS GONÇALVES DA ROSA ${ }^{1}$
}

UFPel

Conheci Augusto Ópẽ da Silva e os Kaingang de Iraí no América Latina, Hacer Nuestra La Integracion, um evento sobre os quinhentos anos da "descoberta" da América pela Espanha, ocorrido em San Javier Misiones, na Argentina, em outubro de 1991.

Naqueles dias eu documentava com uma câmera de vídeo o irreverente e contestador Oi Nós Aqui Traveiz, de Porto Alegre. A Tribo de Atuadores foi contratada pela Central Única dos Trabalhadores para a encenação da peça Dança da Conquista no América Latina, uma criação que mostrava a chegada dos europeus e da igreja na América Latina, bem como seu nefasto contato com os índios.

Lá chegamos e exibimos a peça, tendo na plateia a presença dos Kaingang de Iraí. O público ficou encantado com a encenação. Após o término, Augusto Ópẽ da Silva veio conversar conosco, entregando um panfleto denunciando a situação em que se encontravam os Kaingang. Neste documento estava escrito o seguinte (grifos do original):

\section{Iraí, terra Kaingang! Resistência e luta pela demarcação! \\ Antigamente, antes dos brancos chegarem, os Kaingang ocuparam todo o Alto Uruguai (norte do Rio Grande do Sul), oeste de Santa Catarina, quase todo o estado do Paraná e oeste de São Paulo. \\ Em 1917 a Comissão de Terras e Colonização de Palmeira das Missões-RS, chefiada pelo Sr. Frederico Wesphalen, enviou para Iraí o Dr. Antonio Vilanova para administrar as águas termais (águas que nós, Kaingang, descobrimos). O outro interesse do Sr.}

\footnotetext{
${ }^{1}$ Etnólogo, Professor do Bacharelado em Antropologia e do Mestrado em Antropologia (PPGAnt), Coordenador do Núcleo de Etnologia Ameríndia (NETA), vinculados à Universidade Federal de Pelotas (UFPel). E-mail: rosa.rogeriogoncalves@uol.com.br .
}

Espaço Ameríndio, Porto Alegre, v. 8, n. 2, p. 322-348, jul./dez. 2014. 
Frederico era de trazer os colonos brancos para ocuparem as nossas terras.

Dr. Antonio mandou derrubar todas as matas ao redor das nascentes das águas e construir uma estrada que ligava as águas do Mel até Palmeira das Missões.

Com isso os colonizadores foram entrando e se apropriando cada vez mais das nossas terras, desmatando e construindo casas, vilas e cidades.

Mas nós permanecemos ao lado do Rio do Mel, pescando e caçando. Porém, cada vez mais a caça e a pesca iam sumindo porque os brancos iam destruindo tudo.

Aos poucos fomos sendo cercados pelos invasores e cada vez mais o nosso território foi sendo reduzido.

Durante um bom tempo fomos usados pelo turismo de Iraí. Para nos expulsar daqui a Prefeitura criou em 1979

a Reserva Florestal Municipal na nossa terra.

Mas nós estivemos sempre firmes na luta pela demarcação da terra. O cacique Nonoai, no século passado, foi quem começou esta luta.

Os caciques Galvão de Oliveira, Aristides da Silva e Augusto da Silva deram continuidade na luta pela demarcação da terra.

Mais recentemente, reforçando a luta pela terra, vêm os caciques Enes Mineiro, Avelino Mineiro e Jair Sales, conseguindo mobilizar a comunidade nessa reivindicação.

Fizemos várias viagens a Brasília e a Porto Alegre. Numa dessas viagens descobrimos o processo de demarcação da terra de Iraí estava engavetado nos Ministérios do Interior e da Reforma Agrária. Descobrimos também que o ex-prefeito de Iraí, Urivaldo Pigato, e o deputado federal pelo Rio Grande do Sul, Osvaldo Bender, fizeram pressão política para que a área não fosse demarcada.

A FUNAI fez uma pesquisa para ver se nós tínhamos direito à terra ou não. Em 1985 ficou comprovado oficialmente, através de um laudo antropológico publicado pela FUNAI, que essa terra é indígena e pertence aos Kaingang.

A Constituição Federal (artigos 231 e 232 do Capítulo 8 DOS ÍNDIOS) diz que nós temos direito à terra tradicionalmente ocupada, para nossa sobrevivência física e cultural, ou seja, a quantidade de terra que necessitamos para viver conforme nossos costumes.

Hoje nós sobrevivemos em 74 famílias com 294 pessoas, morando em apenas um hectar de terra. Não temos infra-estrutura, estamos sujeitos a alagamentos da aldeia pelas cheias que ocorrem a cada ano, danificando nossas casas. A vida de nossas crianças 
está sendo ameaçada, sendo que hoje $40 \%$ da população são crianças. Nossa saúde está seriamente comprometida. Nem podemos usar mais a água mineral que nós mesmos descobrimos. Nos sentimos extremamente empobrecidos e carentes da vida digna à que temos direito. Não temos terra para plantar e matar a fome de nossas crianças. Nossa fonte de renda é somente o artesanato. Para fazer o artesanato nós temos que buscar o material muito longe e para vender também temos que nos deslocar para outras cidades.

Por isso estamos intensificando a luta pela demarcação de nossa terra. Estamos buscando o seu apoio nesta luta.

JUNTE-SE A NÓS!!!

Kaingang de Iraí

O panfleto repassado por Augusto Ópẽda Silva teve grande impacto sobre meus pensamentos e, um mês depois, em novembro de 1991, eu estava em Iraí sentado ao seu lado, conversando sobre a realização do vídeo Kaingang de Iraí. Augusto teve um papel de destaque na condução deste projeto.

O texto que segue abaixo traz Augusto Ópẽ da Silva em três momentos, todos marcados pela sua voz: de início, seu trabalho enquanto chefe político na luta pela terra dos Kaingang de Iraí; a seguir, sua espiritualidade e sua ligação ao kujà Pedrinho da Silva Katãn; por fim, a história de Augusto Ópẽ da Silva por ele mesmo, gravada em 10 e 11 de dezembro de 1996, configurada para minha dissertação de mestrado (ROSA, 1998). Intencionalmente, nesse trabalho darei um estatuto de super-humano a Augusto, ou seja, de um sábio chefe político e um guerreiro incansável (ROSA, 2013). A intriga humana desse homem, suas alegrias e tristezas, suas vitórias e derrotas será construída por outros narradores.

\section{A luta pela terra dos Kaingang de Iraí nos anos 1990}

Em janeiro de 1992, iniciávamos as gravações dos vídeos Terra Kaingang e Iraí, Terra Kaingang. Aproximadamente trezentos Kaingang viviam nas suas casas aglomeradas no toldo velho, na barranca do Rio do Mel, em apenas um hectare de terra. As condições dessas pessoas 
em Iraí eram piores que a dos favelados dessa cidade. Augusto Ópẽ da Silva nos fala:

As condições de vida no toldo estão cada vez mais difícil, setenta e quatro famílias em um hectare de terra. Estamos tentando melhorar; esperamos a demarcação da área. A mata está cada vez mais pequena, as ervas medicinais estão ficando poucas. 0 branco está destruindo a floresta de onde a gente tira a taquara para o artesanato, não temos terra para plantar algum milho e feijão (janeiro de 1992).

Os Kaingang de Iraí viviam uma situação dramática. Além de não terem espaço para plantar milho e feijão, a Prefeitura Municipal de Iraí, a Câmara de Vereadores, empresários da hotelaria e grupos ecológicos locais impediam os Kaingang de caçar e de coletar material para fabricarem artesanato. Essas instituições e entidades defendiam a proposta de que os Kaingang deveriam ir para a Terra Indígena Nonoai, cerca de quarenta e dois quilômetros dali.

Em resposta às acusações de que os Kaingang estavam poluindo as águas do Rio do Mel, Augusto Ópẽ da Silva gravou um depoimento em vídeo. Como os personagens mitológicos kaingang que descem para o interior da montanha (BORBA, 1908), Augusto também se reporta à terra-mãe.

A gente só ocupa sessenta metros de distância, ecologistas acusam para tirar índios daí como gente da cidade que diz o mesmo. A própria cidade coloca o esgoto, além dos oitenta metros [quilômetros] que já vem poluindo. Não colocamos veneno na água, fizemos trabalho natural, sem produtos químicos. Tem o esgoto dos hotéis que cai no Rio do Mel, quando o Uruguai sobe vem poluição junto. A terra para nós representa assim, ela é muito importante para nós. É dela que a gente tira o alimento. É dela e do mato também, representa uma importância muito grande. É dela que a gente tira os alimentos natural. $E$ as nossas roças também, nossas rocinhas, sabe. É da terra que a gente faz. E a sociedade indígena ela é muito diferente do que a sociedade branca. Nós, índios, não pensamos em comercializar o produto. Por isso que a gente preserva muito a natureza. Agora, o branco, não. Ele destrói a mata. Porque ele pensa no dinheiro. Nós, não. Nós trabalhemos só para comer o pão de cada dia. Não 
pensemo em ficar rico nem pobre. Assim é sociedade indígena. E a terra é importante para nós porque ela significa uma mãe. Assim como uma mãe tira do seu próprio corpo o alimento para dar vida a seu filho, a gente também. Não usamos produtos químicos na terra, que prejudica a terra. Porque o adubo vai enfraquecendo a terra, sabe. Então o adubo para nós mesmo é a capoeira. Por exemplo, se a gente faz uma rocinha, ocupa aí uns quatro anos e mesma área. Depois nós deixamos ela crescer mato e vai para outra capoeira e faz a mesma rocinha e depois ocupa mais tempo, uns três, quatro anos e depois volta naquele pedaço de novo. É trabalho assim natural, não precisa nem adubo daí para botar na terra (janeiro de 1992).

Apesar das dificuldades que se atravessam nas vidas dessas pessoas, mesmo nas piores circunstâncias - na barranca do Rio do Mel as águas subiam até as casinhas de plástico e taquara - eles não abandonaram a terra dos seus antepassados, não aceitaram ser transferidos dali para outra área, "onde pudessem ter a assistência necessária", conforme tentativas da Funai (EBLING, 1985, p. 71); tampouco aceitaram ir para outro espaço, mesmo que perto dali, a ser comprado pela Prefeitura Municipal de Iraí. As intenções das diferentes instâncias governamentais para com os Kaingang almejavam a liberação do aeroporto, da reserva florestal e das fontes de água termais aos interesses econômicos e turísticos dos empresários iraienses.

Os inimigos não eram poucos, mas o chefe político Augusto Ópẽ da Silva (metade kanhru) era protegido pelo Pedrinho da Silva Katãn (kanhru). O kujà (xamã) Pedrinho participava da luta pela terra protegendo as lideranças kaingang contra as ameaças de morte pelos políticos da região. Augusto Ópẽ da Silva nos conta:

Quando a gente ia viajar, ele fazia alguns ritos dele pra proteger na viagem. E a gente tem viajado muito, enfrentando o perigo e não aconteceu nada com nós até agora. Inclusive o meu nome, ele me deu o nome de Ópẽ, Ópẽ é um gafanhoto, ele percebe muito quando está sendo perseguido, persegue qualquer coisa, então ele solta longe o bichinho. Ele me deu esse pra qualquer perseguimento escapar sempre do perigo (dezembro de 1996).

Espaço Ameríndio, Porto Alegre, v. 8, n. 2, p. 322-348, jul./dez. 2014. 
Nas conversas com os velhos kaingang, eles contam que, na luta dos Kaingang de Iraí contra a Prefeitura Municipal, os grupos ecológicos e os comerciantes, esteve presente a "mão do espírito" do Cacique Nonohay. Augusto Ópẽ da Silva falou sobre a anterioridade de Nonohay (kamẽ) no território reivindicado pelos Kaingang contemporâneos.

Aqui vivia o Cacique Nonohay que era território dos
Kaingang, o Cacique Nonohay vivia por aqui antes de
criar esses municípios. Na demarcação desses 1856 era
de quatrocentos e vinte mil hectares e tinha muitos
espaços; esses municípios estavam dentro desse
território. Foi criado depois Iraí, Alpestre, Nonoai,
Liberato Salzano, novos municípios; todos dentro desse
território que foi demarcado em 1856. O Cacique
Nonohay, muito antes do Fabricio da Silva, sempre
vinha aqui em Iraí, vinha nas águas, e ele foi enterrado
aqui em Iraí; o cemitério dos Kaingang era no parque
do Balneário; eles viviam aí caçando, pescando. Tinha
muita caça e muito mel; aí viviam também os Guarani.
Na época eles tinham acesso livre, tinha muito pinhão,
não tinha crise na época, tinham alimento mais natural,
folha do mato. Mas, quando criaram os vários
municípios, avançou muito a crise. Hoje estamos nessa
área pequena, e hoje tem muita dificuldade.

Pelo lado do pai, Augusto Ópẽ da Silva descende de um Xokleng raptado quando criança; pela mãe, esse chefe político é tataraneto do Cacique Nonohay. Baseado em dados de minha dissertação de mestrado (ROSA, 1998), além da tese de doutorado de Ana Elisa de Castro Freitas (2005) e estudos do indigenista Rodrigo Alegretti Venzon (ROSA, 2009), o mapa de parentesco do Cacique Nonohay e Augusto Ópẽ da Silva possui a seguinte formatação:

Espaço Ameríndio, Porto Alegre, v. 8, n. 2, p. 322-348, jul./dez. 2014. 


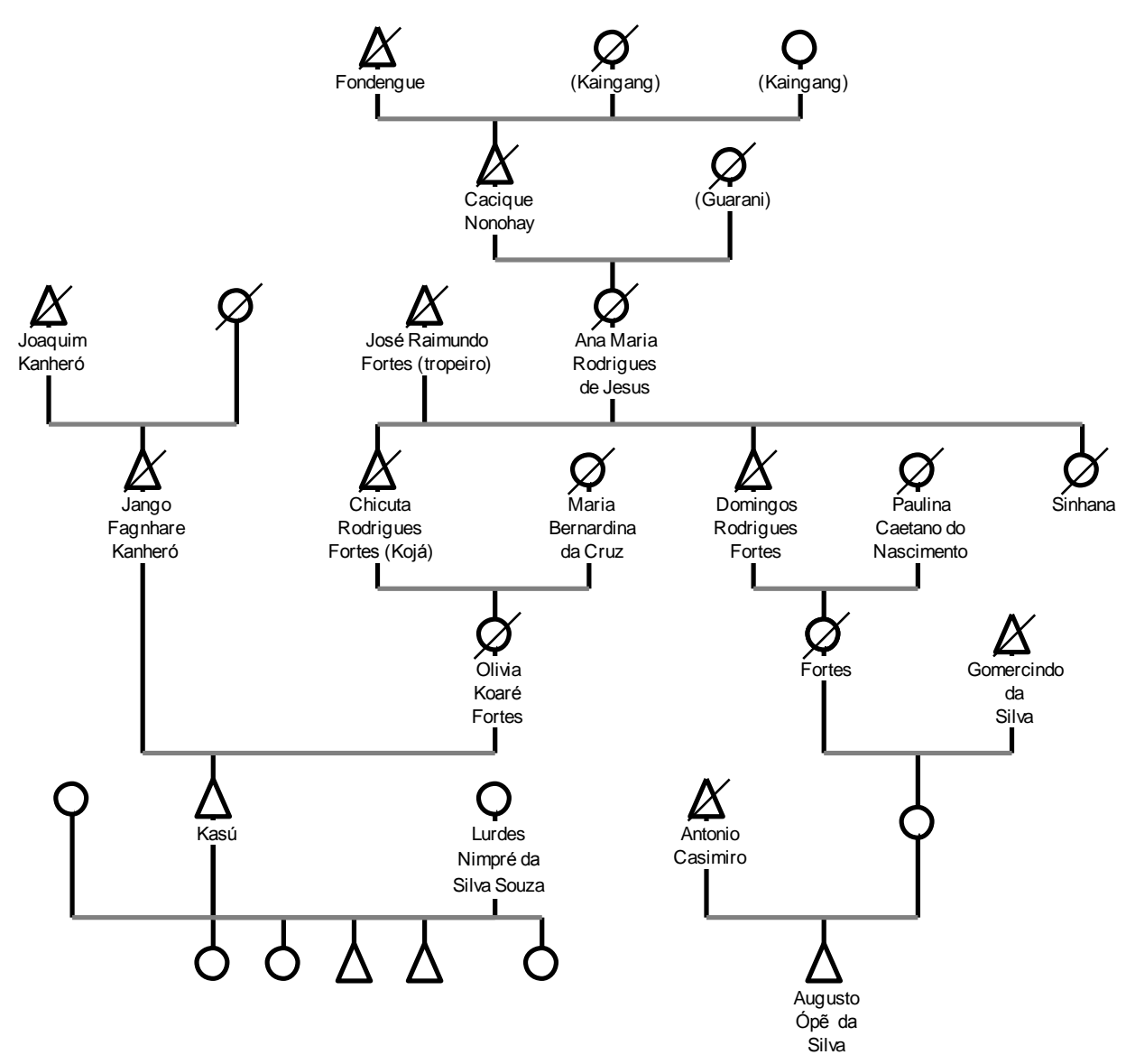

Genealogia: Cacique Nonohay e seu tataraneto Augusto Ópẽ da Silva.

Retomando o discurso político de Augusto Ópẽ da Silva, à medida que foi se intensificando a chegada dos brasileiros nas proximidades das fontes de águas que o espírito do Cacique Nonohay protege, nas décadas de 1930 e 1940, os Kaingang Fabriciano e Bastiãozinho partem então da Terra Indígena Guarita e se instalam, constroem as suas casas na barranca do Rio do Mel, ao lado da cidade de Iraí. Eles fazem isso, trazendo junto suas famílias, inclusive a jovem kaingang Vicentina da Silva, para protegerem as fontes de águas dos "brancos" - além de manterem o vínculo com a memória do Cacique Nonohay. Nas palavras de Augusto:

Fabricio foi o primeiro cacique de Iraí. Conheci o Galvão, ele entrou depois, veio de Nonoai. Ele era muito doente. Foi trocado pelo Aristides. O primeiro cacique, depois que os Kaingang se fixaram mesmo, 
era o Fabricio da Silva. Ele era de Guarita. Em 1984 o pessoal me elegeu para cacique porque a gente entendia um pouco da política de trabalho da Funai, as falhas da Funai e os direitos a gente já entendia um pouco. Hoje a gente tá lutando não só para a questão da comunidade de Iraí, mas para todas as áreas que é a Região Sul. A reivindicação dessa área de Iraí vem há muito tempo. Tinha índios como a Vicentina da Silva foi a Porto Alegre a pé com o pai dela para reivindicar a área, eles iam de Iraí daqui até a Porto Alegre para falar com o Governo do Estado, a pé. Isso foi há muito tempo. Diz ela que tinha uns vinte anos já. Então a reivindicação da área de Iraí vem acontecendo há muito tempo. Quando morreram esses líderes, o pessoal não deu continuidade da luta, não deu a continuidade da luta houve muita redução da área. Daí recomeçamos em 1985 a luta pra demarcar a área, mas as reivindicações da demarcação vem há muito tempo, desde o Cacique Nonoai. O Aristides ficou até a minha entrada. Ficou difícil pra ele. É muito difícil as pessoas mais velhas entenderam a política da Funai, do Governo. A história, a luta, as leis originárias, isso ele era fanático, ele também faz parte da luta. As metades, sobre as metades kamẽ e kanhru e também as leis originárias. Isso também faz parte da luta. Em 84, 0 pessoal resolveu me trocar e daí que ele saiu. Com a idade de dezoito anos a gente começou já a olhar a política da comunidade. A gente aprendeu muito quando a gente acompanhou de várias reuniões. O movimento das barragens, pequenos agricultores, dos jovens, das mulheres. A gente foi pegando a prática. $O$ que o Governo faz com os pequenos. Ali a gente foi pegando a relação com a Funai, a gente foi descobrindo (dezembro de 1996).

Em 1992, mesmo já estando assinada desde 28 de maio a Portaria da Demarcação pelo Ministro da Justiça Célio Borja, a situação dos Kaingang na barranca do Rio do Mel continuava a mesma. Em julho desse ano, em uma assembleia indígena para discutir a demarcação em Iraí, Juvino Sales, então representante da Organização das Nações Indígenas do Sul (Onisul), e João Sateré Maué, da Coordenação das Organizações Indígenas da Amazônia Brasileira (COIAB), propõem a autodemarcação como forma de pressionar o Governo Federal. Há por parte dos Kaingang uma convicção de recuperar "todas as áreas perdidas", conforme as palavras do cacique Jair Sales na época. Os Kaingang também tinham consciência de que o processo de Iraí seria

Espaço Ameríndio, Porto Alegre, v. 8, n. 2, p. 322-348, jul./dez. 2014. 
fundamental, pois o prazo determinado pela Constituição Federal para demarcação das terras indígenas terminaria em setembro do ano seguinte.

No mês de agosto, em meio à chuva e ao barro, sob a liderança do Cacique Jair Sales (kamẽ), do Vice-Cacique Valdemar Vicente (kanhru) e do Augusto Ópẽ da Silva, os guerreiros kaingang, empunhando arcos e flechas, foices e facões, deixam o toldo velho na barranca do Rio do Mel e sobem para o Aeroporto Vicente Dutra. Os Kaingang e alguns Guarani que vieram de Guarita, Nonoai, Ventarra, Votouro e Xapecozinho, contaram com o apoio institucional do Cimi, COIAB, Comin e, particularmente, da organização dos próprios índios, a Onisul.

Naqueles dias, segundo Augusto Ópẽ da Silva, a Funai procurou, por diversos modos, desestabilizar a luta, marcando, na última hora, uma reunião com os caciques - exceção feita a Jair Sales - no dia estipulado para a autodemarcação em Iraí. As indefinições com relação ao dia em que os índios subiriam para o Aeroporto, a espera do apoio formal da Funai, mais o excesso de chuva, desestruturaram o cronograma estipulado pelas lideranças e, consequentemente, a previsão de alimentação. Alguns Kaingang abandonaram a guerra, queixando-se da fome e de muito trabalho. Mas, no geral, as lideranças superaram tais dificuldades e colocaram o primeiro marco simbólico da futura Terra Indígena de Iraí no dia 12 de agosto. 

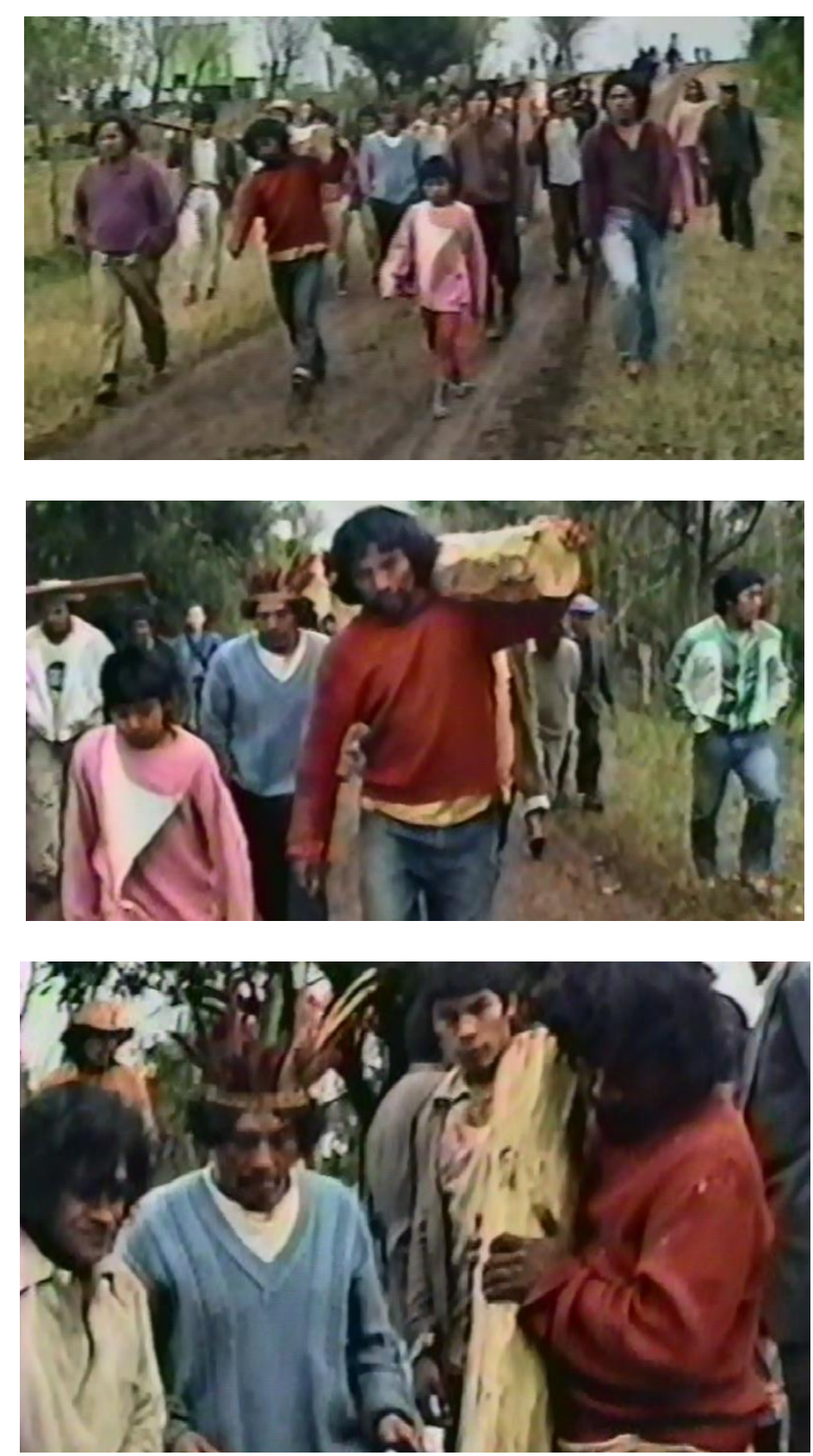

Imagem 1: Sequência Augusto Ópẽ da Silva (blusão vermelho), Cacique Jair Sales (cocar) e kujà Pedrinho.

Quando me reencontrei com Augusto Ópẽ da Silva em novembro do mesmo ano, três meses após a subida dos Kaingang para o Aeroporto, ele disse o seguinte:

Hoje plantamos algumas comidas, feijãozinho, milho, mas a discriminação continua como barraram a construção da escola, era um projeto do Governo Federal. Quando tava levantada a escola, a AIPAN, um

Espaço Ameríndio, Porto Alegre, v. 8, n. 2, p. 322-348, jul./dez. 2014. 
grupo de ecologistas só pra incomodar os direitos, entraram com uma ação, a juíza da comarca do município embargou a construção da escola. Isso é considerado crime de racismo contra a comunidade. A parte da saúde está sendo precária. Quando vamos na LBA, eles dizem que não temo direito. A gente queria cadastrar o pessoal, eles dizem pra nós que não temos direito. A discriminação está sendo forte. Aí por setenta e oito éramos trinta famílias. Havia muitos jovens e foi crescendo, a população, foram crescendo, crescendo filhos. Não tinha espaço pra nada. Morávamos bem pertinho da cidade, na margem do Rio do Mel. Agora temo mais espaço, mas ainda é insuficiente, hoje a população tem uns trezentos índios e duzentos e oitenta hectares de terra.

Em 1993, o presidente da República Itamar Franco homologou a Terra Indígena de Iraí com duzentos e oitenta hectares, onde passaram a viver quatrocentos e vinte e sete Kaingang. Uma das divisas entre a área dos Kaingang e a cidade de Iraí é o Rio do Mel. Seguindo a correnteza da água, nas duas margens do rio, ocupando mais de cem hectares na terra indígena, está a Reserva da Biosfera da Mata Atlântica do Rio Grande do Sul. Mata de onde os Kaingang retiram parte do cipó para confeccionarem artesanato a ser comercializado com os turistas que se dirigem às águas termais de Iraí. No restante da área, poucos hectares são cultiváveis. Por mais que alguns Kaingang se esforcem para cultivar feijão, mandioca e milho, a colheita não garante a subsistência das suas famílias. Os Kaingang seguem dependendo de inúmeros recursos provenientes da cidade. Devido a essa situação, em 2009, Cinthia Creatini da Rocha realiza um estudo antropológico, tendo em vista as reivindicações dos Kaingang em torno de mais uma parcela do seu território invadido pelos "brancos".

\section{Espiritualidade e ligação com o xamanismo kaingang}

Embora Augusto Ópẽ da Silva dialogasse com pessoas de todas as religiões, ele se dizia "católico", sendo bastante ligado ao kujà Pedrinho da Silva Katãn. Não por coincidência, foi essa pessoa que the atribuiu o nome Ópẽ (ganhafoto) e se posicionou ao lado de Augusto quando o 
guerreiro incansável fincou o primeiro marco simbólico da futura Terra Indígena de Iraí. A relação desses dois homens de metade kanhru aparece em outra situação difícil vivida por um filho de Augusto.

Augusto: Lá embaixo [no toldo velho, na barranca do Rio do Mel], quando eu morava, o Sandro [seu filho] ficou doente, faz pouco tempo, e não tinha como ele se recuperar; a alma do meu irmão, que morreu, tinha roubado ele e o meu pai, a minha mãe, tinham roubado ele. Ele andava louco até; ele ia no mato com os amigo dele; diz que ele andava louco no mato; diz que ele arrancava as arvorezinha pequena, quebrava lenha grossa, trepava nas árvores na altura de uns cinco, seis metros e pulava pra baixo...

Autor: Quem fazia isso?

Augusto: O Sandro. Daí eu fui procurar o Pedrinho. Ele disse 'tu vem amanhã, hoje vou procurar ele'. Daí, no outro dia de manhã cedo, a gente foi lá, daí ele descobriu, meu irmão que tinha morrido e o pai e a mãe tinham roubado ele. Ele ia morrer. Se eu não procurasse ele logo, ele ia morrer. Diz que quando o Pedro tava procurando ele, assim no sonho dele, diz que ele tava junto com o pessoal, com meu pai, minha mãe, meu irmão, ele tirando bergamota pra eles. Tava trepado. O Sandro, tirando bergamota, frutas, ele chegou lá; daí ele disse pro Sandro, disse que tava num galho baixo assim, ele chegou lá, perguntou:

- 'o que você tá fazendo aí'?

- 'Tô tirando bergamota pra vó, pro tio'.

- 'Abaixa esse galho aqui pra mim', disse que o Pedro dizia.

Daí ele veio mais na ponta do galho e abaixou onde tava cheio de bergamota; daí quando ele abaixou, ele pegou as bergamotas e puxou mais pra baixo o galho, pegou o galho junto e pegou ele; daí ele fugiu dos velho; daí ele disse agora tem que conseguir umas bergamotas e ele mandou comprar umas vela também, tinha que fazer, tinha que acender a vela lá no cemitério, pros parentes que morreram, pra mãe, o pai, o meu irmão que morreram pra não perseguir mais ele. Eu fiz o que ele pediu. Antigamente nós usava vela, mas assim, nós fazia com cera, e hoje a gente compra vela.

Autor: Tu já perdeu mais um irmão, além desse?

Augusto: Nós era dez. Escapou eu, o mais moço, e a mais velha. A causa da doença na comunidade de Nonoai, morreu um atrás do outro; diz que morreu muitos índios. Outro meu irmão uns, deixa eu ver, faz

Espaço Ameríndio, Porto Alegre, v. 8, n. 2, p. 322-348, jul./dez. 2014. 
uns vinte e sete anos que ele morreu; morreu aqui; esse eu me lembro bem dele.

Autor: Aqui em Iraí?

Augusto: Sim.

Autor: O que aconteceu com ele?

Augusto: Ele se enforcou. Diz o kujà que o Sandro também ia morrer dessa morte, se matar enforcado, se não fosse procurar o kujà.

Autor: Alguém tinha roubado o espírito do teu irmão também?

Augusto: Sim. Tinha roubado. De certo, né, a gente não vê bem; o pessoal às vezes demora pra procurar o kujà (dezembro de 1996).

Quando alguém rouba o espírito de outro, o kujà, que trabalha com um espírito de um animal, vegetal ou santo do panteão do catolicismo popular, tem que trabalhar à noite, deitado, para trazer de volta o espírito seduzido pelos mortos à convivência dos vivos.

A pedido de alguns Kaingang, o kujà Pedrinho da Silva Katãn resolve fazer um remédio do mato. Augusto Ópẽ da Silva leva seus filhos para participarem do ritual, e depois nos conta:

Esse remédio o pajé faz uma vez por mês. É um remédio do mato, né? Antigamente nós usava muito isso. As ramas que aqui estão queimando é para tirar a inveja do corpo, não pegar inveja. Então isso é importante, o costume dos Kaingang. Antigamente nós se curava só com ervas. Então nós temos preservando um costume porque ela é importante para nós, que nossos antepassados usava isso aqui. E o remédio é esse que está no tacho é para lavar as crianças e os adultos também para tirar as doenças do corpo e a fumaça é para tirar a inveja do corpo, não deixar pegar inveja. O pajé ele faz quando algumas pessoas pedem para fazer. Ele faz também. E o pajé ele avisa pra fazer essa fumaça e os banhos de remédio antes de chegar uma doença - uma doença que esteja chegando para atingir a comunidade - ele já sabe. Isso é que nem na campanha de vacinação do sarampo essas coisas e o pajé faz esse costume (novembro de 1992).

Em outra oportunidade, Augusto Ópẽ da Silva explica-me a concepção espiritual dos Kaingang.

Pra falar com Deus, antigamente os índios, eles falavam deitados das informações das nossas pessoas

Espaço Ameríndio, Porto Alegre, v. 8, n. 2, p. 322-348, jul./dez. 2014. 
mais velhas, deitado no chão pedindo a Deus qualquer tipo de problema. Eles conversavam com Deus. E assim também contavam meus tios. Deus é um só que a gente acredita muito, nosso Tupã que hoje a gente sabe que os kujà têm muito contato com Deus e os kujà têm os dons deles, dons deles que é qualquer tipo de animais. Cada kujà tem os seus dons, pode ser um pássaro, um animal de caça, tudo do mato, tudo da natureza. Não é o kujà que vai falar com Deus, é o dom desse kujà que vai fazer os contato com Deus. Depois traz as informações para o kujà. O kujà tem poder porque ele tem dom, vai atrás das coisas porque os Kaingang têm um sentido assim muito diferente, pra nós, quando morre uma pessoa dentro da comunidade, a alma dele está viva; então quando morre uma pessoa adulto dentro da comunidade indígena, o kujà tem que fazer um rito, um rito com os parentes daquela pessoa que morreu, porque se a alma permanece viva dentro da comunidade, ele persegue e muito os parentes, sobrinhos, tios, tenta eles, as pessoas que estão vivas. A alma daquela pessoa que morreu tenta levar eles para o lugar dos mortos. Às vezes as pessoas ficam doentes não tem como se curar, se não procura o kujà logo, aquela pessoa, parente daquele que morreu, morre também, porque leva alma da pessoa viva para o lugar dos mortos. Ele fica, ele rouba a alma da pessoa e se não trazer aquela alma da pessoa perdida, a pessoa acaba morrendo. Então, para defender esses problemas das pessoas, têm os kujà que busca essa alma perdida onde ela estiver. Às vezes, até na viagem, na caminhada, as crianças têm que ser chamada também, quando vai fazer um descanso, descansar no meio do caminho, qualquer descansação, as mães tem que chamar pelo nome quando levanta de novo, segue o caminho, tem que chamar a criança para que não perde a alma daquela criança. Tem de chamar pelo nome kaingang e chamar para que não fique lá perdido, para que acompanhe a alma da pessoa a criança até o final do caminho, até em casa. Se perde a alma da criancinha pequena, a criancinha pequena também fica doente. E se o kujà, se a gente não procurar logo o kujà, se perde e fica doente. Às vezes, as almas daqueles parentes que morreram pegam a alma da criancinha e levam, aí piora, sabe. O kujà tem poder pra isso; ele cura, o dom do kujà que vai procurar; pode ser qualquer lugar, no mato, no caminho, lá no lugar dos mortos — o nũgme [lê-se"numbê"] — nós chamamos de nũgme o lugar dos mortos. O kujà tem que ser uma pessoa muito calma. Ser aberto para todo mundo. Não falar mal de ninguém. Daí que Deus 
manda poder para os kujà. Eles têm uma pessoa, assim, que tem vontade de trabalhar também. Nós confiamos muito no Topé. Hoje têm índios que entendem Topé por Jesus, mas nós entendemo que é, o meu pai contava história pra mim que pra nós mesmo o Deus é Topéfi, seria a mãe de Jesus, não era Jesus pelo que eu entendia. O pai nunca falou assim de Jesus, ele falava Topéfi, então depois eu fiquei pensando, 'então era a mãe de Jesus'. Eles não diziam que Deus era um homem, eles confiam mais na Deusa (dezembro de 1996).

Minha melhor compreensão do significado atribuído pelos Kaingang à "Deusa" aconteceu a partir do cruzamento dessa menção de Augusto Ópẽ da Silva com o diálogo pelo kujà Jorge Kagnãg Garcia e seu amigo kaingang Zílio Salvador, na Terra Indígena Serrinha, acompanhado por mim alguns anos mais tarde.

Autor: O que é Deus?

Jorge Kagnãg Garcia: Se não tem um responsável pelo ar o que não ia acontecer? Por que a lua tem certa altura, o sol a mesma coisa? Para não atingir nós aqui embaixo! Tem que ter um comando que não deixa. Quem é que faz? O mesmo com a energia da terra. Pode existir Deus, é o que governa o mundo.

Autor: Em kaingang, qual é a palavra que define este comando, poder, Deus?

Zílio Salvador: Pra nós é Topé. No nosso idioma, Topé. E pra vocês é Deus, daí. E pros padres, é Jesus...

Jorge:...bem antigo mesmo é kanhkãtóg. Ali começa: kanhkãtóg, rã tóg, kysãtóg, gojtóg. Bem dizer, cada uma destas palavras tem um significado, é o comando...

Zílio:....até as madeiras, até as madeiras...

Jorge:...kanhkãtóg seria Deus. Kanhkãtóg pra nós é o que segura o ar. Kanhkã é o céu; tóg o que segura, o espírito. Antigamente os índios acreditavam no kanhkãtóg dele. Topé foi depois que eles mudaram, veio caindo, veio caindo, vem mudando, mudando também. Dizem assim nas histórias antigas que os avós contavam 'os Guarani que diziam Tupã e o índio pra mudar aquele kanhkãtóg dizia Topé'. Primeiro era kanhkãtóg. O rãtóg é o que comanda o sol, kysãtóg é o que comanda a lua, gojtóg é o que comanda a água, ngatóg é o que comanda a terra. Tudo tem tóg [lê-se "tõn"]. Minfygtóg são os passarinhos. O tóg deles é Deus. É o que comanda as coisas. Sem ter uma força que atenda nada se cria. É como a gente acredita. O 
que é este tóg? Nga Tóg é o regimento da terra [...]. Na parte kujà, eles têm este alcance. Ele pensa, pensa, pensa até que chega à ideia dele. Eu calculo que é assim: Deus que a gente fala ele comanda tudo isto aí, um mandato (fevereiro de 2012).

A partir do cruzamento do conceito de tóg com a perspectiva do sistema kujà e do sistema caboclo, que formam o complexo xamânico kaingang, o diálogo travado por estes dois kofá (velhos) amplia o nosso conhecimento sobre a espiritualidade kaingang, o poder e a floresta (natureza). Ou seja, no sistema kujà, tóg é "Deus", o "espírito", o que "comanda" o sol, a lua, a água e todos os seres que habitam na terra, determinando tanto uma diversidade quanto uma unidade, afinal, nas palavras de seu Jorge, "tudo tem tóg. [...] O tóg deles é Deus". No sistema caboclo essa característica se replica: Topé é "Deus", configurando igualmente tanto uma diversidade, pensando, por exemplo, no conjunto de santos que caminham pela terra, conforme as narrativas kaingang, quanto uma unidade, "Deus". Na lógica do xamanismo kaingang, tóg é o poder que rege cada um e todos os humanos e os demais seres - animais, vegetais, minerais, líquidos, fluidos e celestiais - que estão no mundo (ROSA, 2005 e 2014). Em resumo, aproximando os relatos de Augusto Ópẽ da Silva, Jorge Kagnãg Garcia e Zílio Salvador, a noção de Topéfi ou "Deusa" pode ser entendida como sendo a "espiritualidade da floresta".

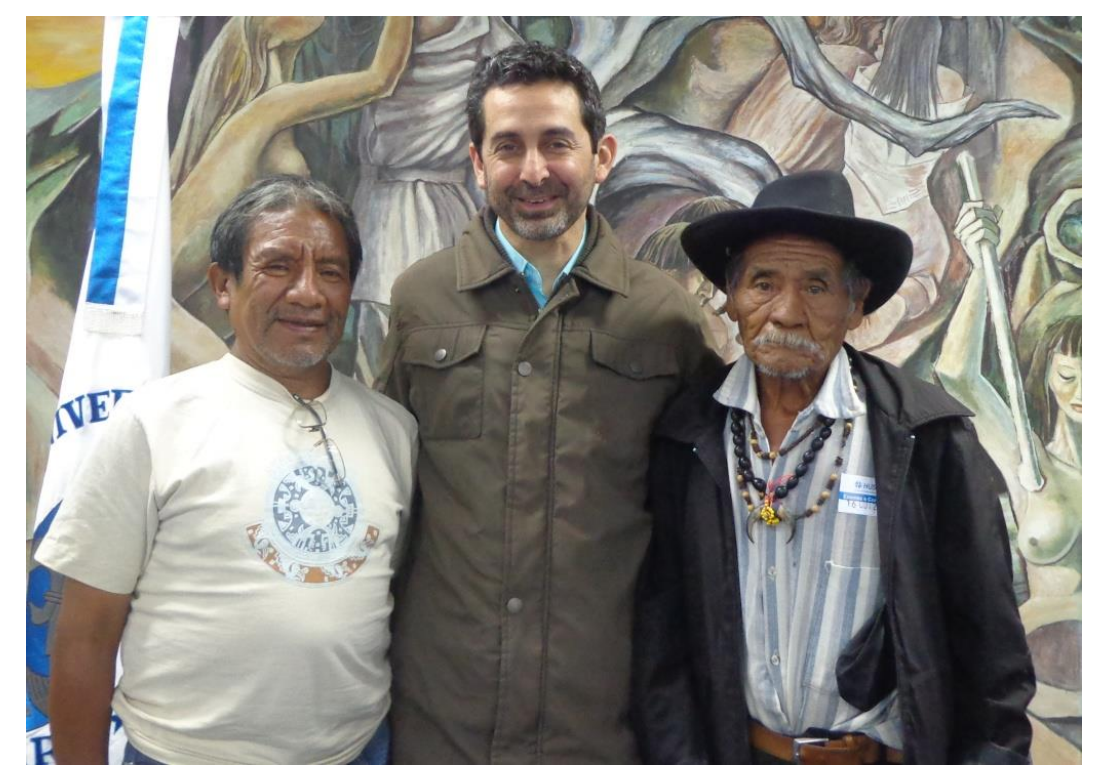

Imagem 2: Augusto Ópẽ da Silva, Rogério Rosa e Jorge Kagnãg Garcia (outubro de 2013).

Espaço Ameríndio, Porto Alegre, v. 8, n. 2, p. 322-348, jul./dez. 2014. 


\section{Augusto Ópẽ da Silva por ele mesmo}

Nas páginas seguintes trago, na totalidade dos parágrafos, Augusto Ópẽ da Silva pela sua voz. A conversa com Augusto, gravada nos dias 10 e 11 de dezembro de 1996, aconteceu no pátio da sua casa, enquanto ele confeccionava artesanato para vender nas cidades por onde eleviajaria nos dias seguintes para divulgar a luta dos Kaingang no sul do Brasil e dos povos indígenas.

Meu nome é Augusto Ópẽ da Silva, sou liderança da área de Iraí. Eu nasci fora da área porque naquela época surgiu a tal de SPI, Serviço de Proteção ao Índio, mas na verdade era para massacrar os índios. Os índios trabalhavam de graça pro SPI, trabalhavam na roça, assim de escravo. Assim que meu pai saiu de Nonoai, eu não tinha nascido, minha mãe saiu fora da área grávida. Onde que eu nasci fora da área. Quando eu nasci, meus pais voltaram de novo pra área de Nonoai, só que a exploração, os escravos, não tinham parado ainda, tavam acontecendo. Minha mãe morreu fora da área por causa de todo o problema do SPI. Muitos índios saíam da área para não trabalhar de graça pro funcionário do SPI. A gente nem chegou a conhecer a mãe, minha mãe morreu quando eu tinha três anos. Eu me criei nas mãos de meus tios, minhas tias, e com a idade de doze anos a gente veio para Iraí, onde que a gente se criou, ficou rapaz, ficou adulto, e a gente casou com uma índia de Serrinha. Faz vinte e poucos anos que a gente somo casado, outra índia que é de Serrinha. Ela também veio expulsa de Nonoai, onde a gente se conheceu, e, em 1985, a gente começou a luta pela demarcação da terra de Iraí. Na época, os funcionários do SPI diziam para os índios que era pra fazer casa, comprar medicamento, comprar material escolar, eles exploravam as lideranças indígenas, eles compravam as lideranças indígenas para ajudar a massacrar os seus parentes. As lideranças não sabiam que tavam enganado, então isso aconteceu muito nessas áreas aqui, Nonoai, Inhacorã, Guarita. E ouve muitos índios espalhados no país hoje, índio fora da aldeia. Tem

Espaço Ameríndio, Porto Alegre, v. 8, n. 2, p. 322-348, jul./dez. 2014. 
índios que hoje moram nas favelas da cidade por causa desse trabalho do governo, tem índios que esqueceu da sua própria língua. Massacre muito preocupante.

Era o panelão. O panelão era formado cada comunidade ser uma área grande, várias comunidades tinham que trabalhar de graça, mesmo que você tivesse sua esposa dentro morrendo de doente, 0 filho doente quase morrendo de doença, o índio tinha que ir igual; e se não fosse trabalhar eles pegavam os índios e enfiavam na cadeia. Um escravo muito grande quando surgiu o SPI. Minha mãe, Rosa da Silva, faleceu quando eu tinha três anos, depois nós, quando a mãe morreu, meu pai, Antônio Casimiro, contava pra mim que nós fomo de volta pra Nonoai. Daí, com a idade de seis anos, a gente voltou pra fora da área, nós fomos lá pra Santa Catarina, Cunha Porã. E nós vivia né, o pai trabalhava de peão para os colonos, sustentando, enquanto nós era pequeno, eu tinha uma outra irmã mais velha do que eu. Aí depois, quando eu tinha oito, dez anos, meu pai me adotou para minha tia, minha tia Josefa Pinto adotou, que era irmã mais nova do meu pai. Daí que eu cresci e daí com a idade de doze anos, do Cunha Porã, nós voltamos para Iraí. Faz quase trinta anos atrás, são essas duas áreas que nós moramos. Os da Silva eram os kamẽ, aquela houve mistura daí, meu pai é kanhru puro, kanhru puro, minha mãe também. Meu pai faleceu em São Carlos, Santa Catarina, pechada de carro. Com todo esse trabalho mal feito pelo governo, meus pais morreram tudo fora da área. Minha mãe nem conheci. Nós tava em Santa Catarina porque tem umas águas onde vem turista e nós estávamos vendendo artesanato lá, onde que ele foi visitar outra irmã, daí ele saiu do acampamento. Nós ficamos sabendo através da polícia que um índio tinha morrido num hospital de São Carlos. Lá em Nonoai havia o panelão, as pessoas que não queriam trabalhar no panelão saíam para procurar artesanato como uma forma de ganhar sustento, e trabalhava de peão assim pros colonos pra fora da área, Santa Catarina, São Paulo, Paraná, nessas cidades. Nessas colônias, eles saíam a trabalhar, pelo menos eles não eram assim escravo do que o SPI estava fazendo dentro da área, dentro da própria área. Eles viviam, não queriam trabalhar de graça. Eles trabalham um pouco na roça, 
quando tinha colheita de feijão e milho, eles trabalhavam nos colonos, ganhavam um sustento para os seus filhos, eles não tinham como trabalhar para si mesmo porque tinham que trabalhar para os funcionário do SPI, pra eles não tinham tempo porque eles eram escravo. Não sobrava tempo pra eles plantar pra eles, pra fazer autossustentação com a sua família. Era muito difícil porque o SPI pressionava muito e as lideranças também, eram comprado, eram comprados pelo SPI para ajudar a escravizar os seus próprios parentes.

O irmão mais velho do meu pai, que se chamava Joaquim Casimiro, era comprado. Meu pai brigava muito com o tio. 'A coisa não é por aí, isso não era bom explorando nossos próprios parentes'. 'Se você quer vir contra a gente, vai ter cadeia pra você ficar lá dentro'. Outro que ajudou a explorar foi o meu primo, filho desse Joaquim Casimiro. Hoje ele é aposentado como funcionário do SPI. Joaquim Casimiro era liderança de uma comunidade. Tinha capitão, coronel, mas quem governava toda essas lideranças era o próprio SPI. Quem era cacique dentro da área era os funcionários branco, do governo. Agora que as lideranças estão enxergando, têm uma visão mais preocupante, mais longe, por causa os novos se organizaram e foram procurar os seus direitos, então hoje é muito difícil o índio ser escravo da Funai, agora. Que nós pra lutar pro nossos direitos quando nasceu a Funai, nós não tinha festa pra se visitar uma área na outra, pra trocar de ideias, para reivindicar nossas terra que o governo tinha tomado de nós. Nós não tinha acesso, nós tinha que usar portaria, ficava um tempinho determinado, dois, três dias pra visitar parente tinha que ter uma portaria. Se chegasse sem portaria duma área pra outra os funcionários da Funai e lideranças enfiavam aquela pessoa na cadeia e até as lideranças daquela área vir buscar seu índio. A luta não avançou por causa disso, a luta pela terra não avançou por causa que esse trabalho que a Funai fez, fez a portaria para se visitar. Mas antes nosso pai nos contava que ia a pé de Nonoai até Guarita, Votouro, Serrinha, trocando de ideias, protegendo suas terras, suas divisas. Só que quando nasceu a Funai, complicou, sabe. Não tivemos mais acesso pra se visita, não houve mais troca de ideia. Em sessenta e dois, o governo fez a reforma agrária, em cima das terras 
indígenas e não houve trocas de ideias. A Funai na época não se preocupou com essa tal de reforma agrária, como ela era responsável para com os povos indígenas, só que quando surgiu esses problemas, eles não se preocuparam, mas a gente foi aprendendo as coisas. Eles não se preocuparam com os índios, mas a gente foi aprendendo as coisas, a luta, as terras, a importância da terra hoje pra nós. Daí, noventa e um, nasceu as organizações indígenas com bastante dificuldade. No comecinho de noventa e um, nós tinha daí a Onisul. E a Onisul andava assim, muito perseguido pelo órgãos do governo, eles não se deixavam nós se organizar para reivindicar nossos direitos. E apesar de tudo essas perseguições, e até mesmo os políticos que não gostam das questões indígenas, a Onisul avançou num trabalho muito importante e conseguimos reivindicar nossas terras. Não foi tão fácil pra nós ter acesso entre as lideranças porque a Funai não deixava encaminhar nós, mas, mesmo assim, a gente conseguiu criar várias organizações, organizações indígenas, foi criada a associação dos professores que é a APBKG, Associação dos Professores Bilíngues Kaingang e Guarani, organizamos curso de enfermagem, de língua; conseguimos também demarcar essa área de Iraí com a articulação, com organização indígena e também as entidades de apoio, entidades não governamentais, conseguimos reivindicar várias áreas. Através desse trabalho, as áreas indígenas que o governo tinha tomado em sessenta e dois voltaram a ocupar as áreas que é o Ventarra, Monte Casero, agora Serrinha, mais recente ocuparam essa área. O movimento avançou bastante, quando nasceu a Onisul, e aí nós pensamos como tinha várias organizações, nós temos a articulação que nasceu agora há pouquinho tempo que é a Apois, que hoje tá avançando a luta da terra. Com tudo esse trabalho, mal feito pelo governo, quem sofre com isso é os dois pequenos grupos, a comunidade indígena e os pequenos agricultores que tem em cima das terras indígenas. O objetivo da nossa organização é lutar junto porque nós sabemos que os agricultores que tem em cima das terras indígenas, eles não são culpados por estarem em cima das terras indígenas. Temos que pressionar a Funai para indenização das benfeitorias e pressionar o Incra para o assentamento. As 
pessoas que foram expulsadas, as da Serrinha foram expulsados para Nonoai, uma área maior; Ventarra foi para a área de Votouro; Monte Casero foram espalhados em várias áreas, Ligeiro, Carreteiro, Nonoai, Guarita, e alguns tinham que sair da área, não podiam voltar mais para a área, por isso tem gente morando em favela nas periferias da cidade. Tem muito descendente índios na periferia das cidades. O governo não podia ter feito reforma agrária nas terras indígenas. Tem a área de Borboleta, que é uma área muito grande, que está sendo reivindicada hoje, onde que os índios, eles carregavam os índios assim como carregar animais em caminhão, foram expulsados, trazidos para a cidade e hoje eles estão morando em Cruz Alta, Porto Alegre, depois que saíram dessa área de Borboleta.

Meu pai contava pra mim, os órgãos do governo eles tentam comprar as lideranças. Meu pai sempre me orientava, 'nunca pode fazer isso com os parentes; sua mãe faleceu, você se criou fora da área, por causa do seus tios eles se venderam para os órgãos do governo. Você nunca pode fazer isso com a sua comunidade'. A gente não teve essa influência de explorar os parentes. A primeira viagem que a gente fez para Porto Alegre, na Delegacia Regional de Porto Alegre, a Funai ofereceu emprego para mim. Ofereceu estudo para fazer supletivo e segundo grau. A Funai me prometeu que ia pagar todos estudos, ia sustentar minha família e quando eu tivesse formado ia ser funcionário da Funai. Pensei pra mim mesmo, tava eu e mais três comigo, Enes, Valdemar, Alcir Salvador. Eles ofereceram estudos para nós quatro. Eu sabia que a Funai queria enrolar, queria comprar nós. Sentamos numa salinha e discutimos. Eu disse, 'eu não acho bom porque a recém estamos reivindicando a área, isso não vai ser bom; outra coisa que vai atrapalhar, quando a gente estudar vamos parar de reivindicar a área'. São vários tipos de relação que eles tentam cooptar as lideranças. A gente se cuida muito disso, os meus parentes sofreram há muito tempo atrás, sofreram bastante. Eu não quero mais que isso aconteça com meu povo. Isso foi em oitenta e cinco, quando a gente cobrou pela primeira vez a demarcação da área de Iraí. Hoje a gente podia ser um delegado da Funai. Não quis. Pela história do meu pai ele me orientava. A gente não tem essa vontade de ser enrolado pelos órgãos do 
governo, a gente não quer passar bem e os meus parentes passando mal. Se eu sofro todo mundo tem que sofrer junto. Nossos parentes têm que estar junto. Nós somos pouco, nós somos a minoria. Outra questão que a gente pensa, nós não quer que acabe a nação indígena, temos que se orgulhar ser índio pra sempre porque se continua assim a compra de lideranças, onde nossos parentes vão sendo mais massacrados e vão deixando de ser índio, índios morando fora da área. Depois que a gente saiu, depois que eu saí de cacique, daí entrou o Enes. Nossa política de trabalho era de sempre estar junto, trocando ideias; depois entrou o Avelino Mineiro; depois entrou o Jair Sales; depois entrou o Valdemar. A autodemarcação foi na época do Jair, em 92. Nossa política de trabalho era assim: mesmo que sai de liderança, de cacique, nós devia estar junto, lutando, reivindicando as necessidades da comunidade. Porque tem algumas áreas que quando trocam de lideranças entram lideranças novas, 'agora eu sou o cacique, mando sozinho'. Tem que estar junto trocando ideias, aquele que foi liderança tem experiência; o trabalho da gente tá sendo assim, até agora, e vai ser assim pra sempre. A gente vai trocando de experiência quando tem alguma coisa para reivindicar. Eu assumi vários tipos de trabalhos, conselho de mata atlântica, acompanhei a luta contra as barragens na Região Sul, que atingiam muitas terras. Sete áreas indígenas estavam sendo atingidas com essa barragem, construídas na Região Sul. A gente não podia estar junto da comunidade vendo essas coisas internas, a gente sempre defendeu as outras áreas, levar informações pros outros caciques, qual é o tipo de trabalho tem que ser feito para reivindicar essas áreas, foram vários tipos de trabalho, sempre tem que ter uma liderança que saiba atender os problemas internos das comunidades. Os caciques velhos tinham uma maneira de ficar mais dentro da área, e isso mudou.

Eu sou membro da Apois e faço parte do Projeto da Reserva da Biosfera da Mata Atlântica. A reserva da mata atlântica está ligada ao Banco Mundial. Vamos discutir muito isso: o que é mata atlântica pra nós? Pensar em reflorestamento onde os brancos derrubaram as nossas florestas. Ventarra não existe mais mata. Onde os índios voltaram a ocupar estamos pensando em projeto.

Espaço Ameríndio, Porto Alegre, v. 8, n. 2, p. 322-348, jul./dez. 2014. 
Tem que existir alguma coisa para recuperar esse solo, essa terra por causa do veneno que os brancos colocaram. Com todo esse trabalho, a gente tem que estar discutindo nas comunidades. Faço parte do Nisi, do Conselho da Comunidade, eu sou coordenação na CEBs, aquele movimento que luta pela vida, movimento negro, do trabalhador, e a gente está na coordenação, tive uma reunião lá em Goiânia. Nós temos muitos aliados, apoiamos muito o movimento dos negros, então tem vários aliados, nossos irmãos negros. Enquanto que nós tava sendo explorado aqui no Brasil, eles estavam sendo escravos e morto no país deles na África. Nós somos as duas raças que sofreram mais na época da colonização do massacre, hoje temos que trabalhar juntos e reivindicar nossos direitos. Quando os portugueses vieram para o Brasil, já eram acostumados a explorar os pequenos no país dele. Não é só índio que tá sofrido hoje, vários aliados que nós temo hoje em dia. A situação dos povos indígenas também é tudo igual, luta pela terra, e o sofrimento, a dificuldade, as precariedades que tá surgindo é tudo a mesma coisa. Só que nós somos tribo diferente, a luta é a mesma, tem também os costumes tradicionais que a gente se respeita nessa tradição. O índio guarani tem um costume diferente do que os Kaingang. Nessa questão, os Guarani respeita a nossa cultura. Essas duzentas tribo têm uma cultura diferente, uma organização diferente, até no modo de fazer artesanato, na língua, nas histórias, nos rituais são diferentes. Nessas coisas a gente se respeita. Eu não vou botar os meus ritos dentro da comunidade dos Guarani, nem os Guarani podem colocar as coisas dentro da comunidade kaingang. À luta, convivamos juntos, mas sempre se respeitando a cultura de cada povo. Questão de terra, tudo isso é diferenciado, parte da agricultura. Os grandes capitalismos, eles acham que a terra é um instrumento de gerar riquezas. A terra é para nos sustentar, sustentar nossos filhos, não para ficar rico. Parte da saúde é muito diferenciada, tem índios mais velho que não falam o português. Parte da educação, somos diferenciados; hoje nós nos obrigamos a aprender o português porque a gente tem que saber se defender; qualquer repartição pública e falar o português. Ter voz lá dentro, saber defender as nossas terras; entender a política do governo, ter sempre essa educação 
diferenciada; nossos professores bilingues que escrevem kaingang não tão sendo contratado pelo órgão do governo. Escrever o kaingang, o guarani porque tudo isso é diferenciado. Levar a história para nosso filhos; porque nós índios nunca escrevemos num papel a nossa história. A história passa de pai para filho. O futuro para nossos filhos é a terra porque sem terra os índios não vão viver sem terra. Não existe nada mais importante do que a terra para nós índios, esses pequininhos tá crescendo a população cada vez mais. Elas vão crescer, tão crescendo a população cada vez mais; eles vão precisar de terra. É assim que nós estamos pensando. Reivindicar terras; num tamanho que pode a população viver em cima da terra e manter sua tradição, sua língua. Sem terra não existe futuro para nós.

A fonte de renda é um pouco de artesanato, um pouco na agricultura. Trabalho de autossustentação na agricultura. Eu planto feijão, milho, mandioca, batata. A gente tá pensando em plantar arroz; comidas básicas que a gente usa dia a dia. Depois dos quatro anos já que comecei a plantar na área. Nós, Kaingang, aprendemos a ser agricultores. O que destruiu muito a nossa cultura, como se faz agricultura na cultura dos Kaingang? Quando entraram Funai, eles destruíram, ensinaram os índios a plantar soja. Soja é um produto que nós índios não come, mas antes nós plantava só para autossustentação. Plantava de tudo, mas só para autossustentação. Depositava o milho em galpão; o feijão também, tinha alimento pra sempre. Só que quando a Funai ensinou as comunidades indígenas a fazer esses projetos de plantar soja aí os índios aprenderam a comercializar os produtos, e então foi um erro muito grande da Funai ter ensinado nós índios trabalhar nesse sistema capitalista. Nós índios não têm jeito, os índios não aprender ser assim capitalismo. Não tem, os índios nunca plantaram assim para colocar bastante dinheiro no bolso. Então o índio não tem como entrar no capitalismo, eles não sabem aproveitar o dinheiro que eles ganham. E a Funai acha que eles vão virar capitalismo e vão terminar com a cultura deles. Aí que surgiu também o arrendamento nas áreas, todos os prejuízos que hoje existem nas áreas é culpa dos órgãos do governo. Tiveram que aprender porque a invasão estava avançando, a alimentação natural tava sendo pouco, o pinhão 
estava em quase todas áreas acabado. O sistema de depositar o pinhão para outra coleta, outro ano, esse dava pouco não tinha como depositar porque as matas ficaram, foram ficando pouco, daí que eles começaram a trabalhar, plantar milho, plantar feijão.

A evangelização destruiu a religiosidade indígena, ela destruiu bastante quando veio a invasão. Até mesmo a igreja católica; não respeitaram nossa religiosidade; não respeitaram nossos kujà, nossos curadores e entrou várias igrejas, houve várias divisões, entrou os pastores, diziam para os índios que não eram pra andar juntos com os que não frequentam as igrejas. A igreja católica tentou ajudar só que ela não respeitou nossa religiosidade. Nós temos que voltar nossa cultura, ter casa de cultura onde a gente faz o trabalho junto com o kujà, faz as dança tradicionais do Kaingang pra ensinar as crianças. Essas duzentos tribos, todos eles têm um jeito de evangelizar; os brancos tudo isso têm um jeito de evangelizar na época. Agora, tá tudo assim misturado; mas nós índios, a ideia da nossa organização é voltar naquele costume antigo, as festas tradicionais, os ritos, a dança; os kujà que faz as curas, embora que nossas florestas tão acabando a gente tem voltar pra esses costumes antigos. A gente pensa, todas as nações têm suas evangelizações, mas num jeito diferente. Já perdemos nossa evangelização, voltar a evangelizar, mas num jeito nosso. Cada nação tem que saber 0 jeito evangelizar do índio. Nós queremos resgatar tudo isso que eles discriminaram. Não temo casa onde o kujà pode fazer um rito. Casa de cultura é mais importante pra nós. A cultura originária, os ritos feitos pelo kujà, pelos curadores, não pode acabar dentro das comunidades indígenas. Muita gente pensa que a cultura, o passado não volta mais, mas eu acho que não é por aí. A gente tem pensado: o nosso futuro que é do passado, que a gente resgata a história, resgate das culturas a gente tem que trazer para o presente e passar para o futuro para que a nossa nação nunca acabe. Nós queremos continuar sendo índio pra sempre, sabe, uma casa de cultura pra nós fazer os ritos pra ensinar as crianças, que têm algumas comunidades que não lembram mais das danças kaingang. Então, essa casa de cultura seria pra ensinar as crianças que perderam, porque com esse processo de trabalho mal feito pelos órgão do 
governo tem muitos índios espalhados que esqueceram até a língua, que esqueceram até seus ritos. $E$ eles têm interesse de voltar a conhecer tudo as culturas. Toda a cultura verdadeira. Toda a cultura originária.

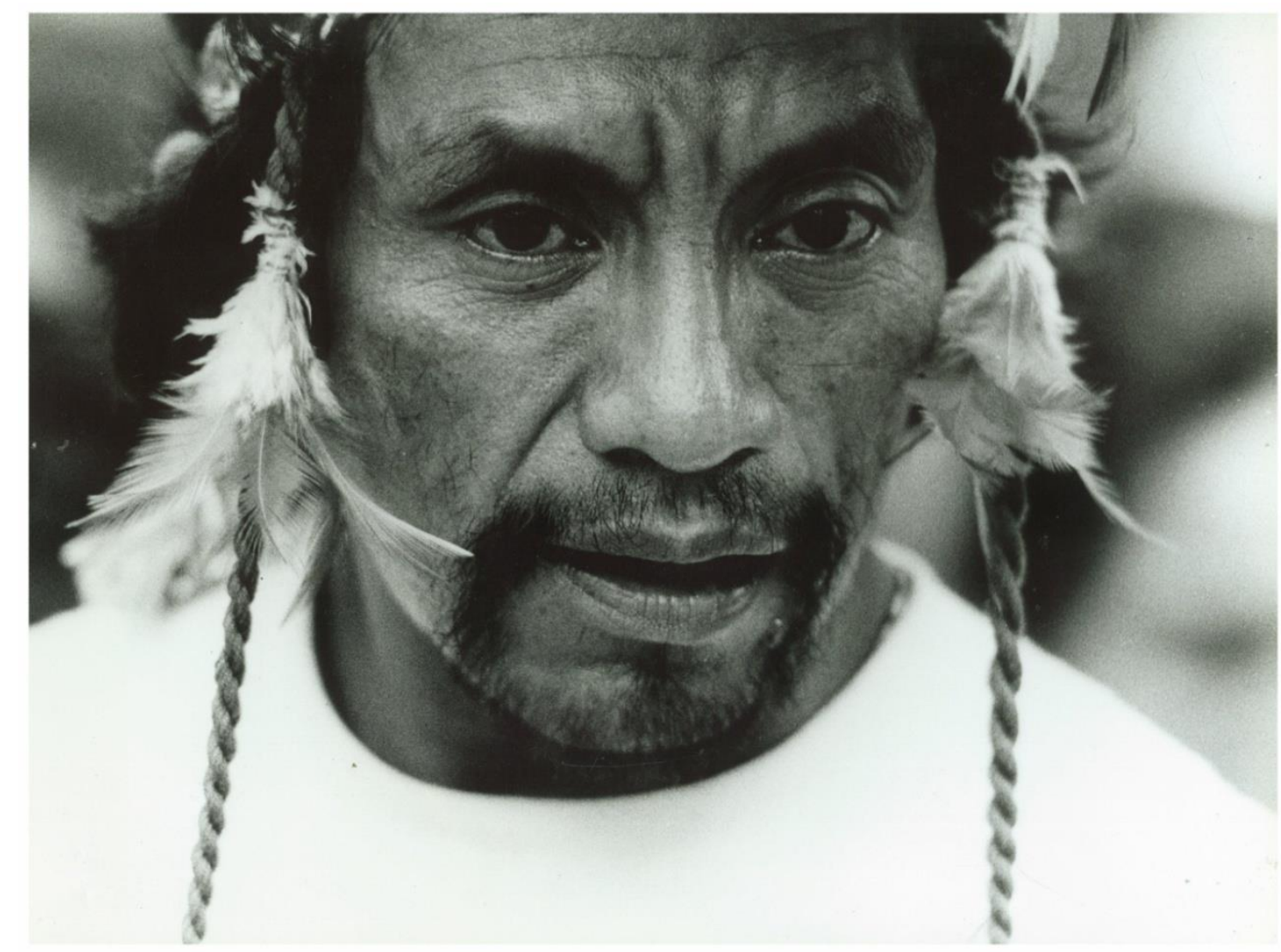

Imagem 3: Augusto Ópẽ da Silva (Porto Alegre / 1994).

Foto: Rene Cabrales.

\section{Referências bibliográficas}

BORBA, Telémaco Morocines. Actualidade Indigena. Curitiba: Imprensa Paranaense, 1908.

EBLING, Paula E. Ruth. Relatório Antropológico de Identificação da Área Indígena de Iraí. Porto Alegre: Funai, 1985.

FREITAS, Ana Elisa de Castro. MrûrJykre - A Cultura do Cipó: territorialidades kaingang na margem leste do Lago Guaíba, Porto Alegre, RS. 2005. 457 f. Tese (Doutorado em Antropologia Social) - Universidade Federal do Rio Grande do Sul, [2005].

Espaço Ameríndio, Porto Alegre, v. 8, n. 2, p. 322-348, jul./dez. 2014. 
ROSA, Rogério Reus Gonçalves da. A Temporalidade Kaingang na Espiritualidade do Combate. 1998. 186 f. Dissertação (Mestrado em Antropologia Social) Universidade Federal do Rio Grande do Sul, [1998].

. "Os Kujà São Diferentes": um estudo etnológico do complexo xamânico dos Kaingang da Terra Indígena Votouro. 2005. 416 f. Tese (Doutorado em Antropologia Social) - Universidade Federal do Rio Grande do Sul, [2005].

Lenda e Mito do Cacique Nonohay Guerra e Vingança Kaingangue no Fio do Tempo. In: KERN, Arno; SANTOS, M. Cristina dos; GOLIN, Tau (Org.). Povos Indígenas. Passo Fundo: Méritos, 2009. p. 137-160.

A Relação Afro-Ameríndia do Negrinho do Pastoreio e do Saci-Pererê na Mitologia. Antares: Letras e Humanidades, v. 5, n. 10, p. 175-203, 2013.

O Xamanismo Kaingang: a relação dos kujà com os espíritos animais/vegetais da floresta e os santos do panteão do catolicismo popular. In: FLECK, Eliane Cristina Deckmann (Org.). Religiões e Religiosidades no Rio Grande do Sul: Manifestações da Religiosidade Indígena. São Paulo: Associação Nacional de História, 2014. p. 97128. v. 3.

Espaço Ameríndio, Porto Alegre, v. 8, n. 2, p. 322-348, jul./dez. 2014. 